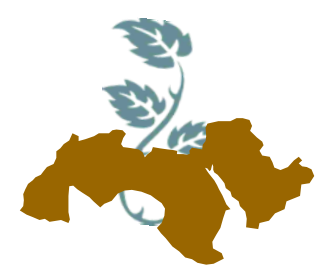

\author{
1993 \\ Arab Univ. \\ J. Agric. Sci., \\ Ain Shams Univ., Cairo \\ Special Issue, 26(2C), 1993 - 2000, 2018
}

\title{
POPULATION FLUCTUATIONS OF IMMATURE STAGES OF THE CITRUS FLOWER MOTH, PRAYS CITRI MILL. (LEP.: HYPONOMEUTIDAE) ON LIME TREES
}

\author{
Badr A.F., Hekal A.M. and Youssef L.A. \\ Plant Protection Dept., Fac. of Agric., Ain Shams Univ., P.O. Box 68 Hadayek Shoubra, 11241, \\ Cairo, Egypt
}

Keywords: Prays citri, population fluctuations, lime trees

\section{ABSTRACT}

Mean numbers of immature stages of Prays citri Mill. on lime flower buds showed six annual population peaks of $13.3,1.2,1.8,6.2,2.8$ and 3.4 in mid-May, mid-Oct., mid-Nov., mid-Dec., midFeb. and mid-Mar., respectively during 2015/2016 season. Five peaks of $13.5,14.5,1.8,5.8$ and 5.0 immature stages were observed on flowers in midApr., mid-June, mid-Oct., mid-Dec. and mid-Mar., respectively. On newly formed fruits, five peaks of $7.3,0.4,2.2,1.8$ and 2.4 immature stages were also recorded in the middle of June, Oct., Dec., Feb. and Mar., respectively. The general mean was the highest (11.3 immature stages) in June, while it was the lowest (0.0 immature stage) in Sep. The highest population density of $P$. citri was recorded in spring, followed by summer then winter and autumn. The seasonal mean was 4.1 immature stages in 2015/2016 season.

The same trend could be applied during 2016/2017 season. Six peaks of $12.8,2.5,4.0,5.8$, 3.3 and 4.6 immature stages were estimated on lime flower buds in mid-May, mid-Oct., mid-Nov., mid-Dec., mid-Feb. and mid-Mar., respectively. Mean numbers of $P$. citri immature stages on flowers also exhibited six peaks of $14.5,2.8,5.3,7.2$, 4.3 and 5.6 in mid-Apr., mid-Oct., mid-Nov., midDec., mid-Feb. and mid-Mar., respectively. Six peaks of $5.8,1.0,1.8,3.0,1.5$ and 2.4 immature stages were also found on newly formed fruits in the middle of May, Oct., Nov., Dec., Feb. and Mar., respectively. The highest general mean was 10.8 immature stages in May, while the lowest was 0.0 immature stage in Sep. The highest population density of $P$. citri occurred in spring, followed by summer then winter and autumn. The seasonal mean was 4.6 immature stages in the second season.

\section{INTRODUCTION}

$P$. citri is an economically important pest infesting different species and varieties of citrus in several continents (Anonymous, 1982; Silva et al 2006; Toth et al 2009; Conti and Fisicaro, 2015). Lime, lemon, sweet orange and navel orange were more susceptible host plants to the pest infestation, while grapefruit, sour orange and mandarine were more resistant ones (Shehata, 1982; Ibrahim and Shahateh, 1984; Abo-Sheaesha, 1987 and 1994; Abd El-Kareim et al 2017). Volatile oils in citrus flowers contain different chemical compounds having odors, which stimulate or inhibit females to lay eggs on susceptible or resistant plants, respectively (El-Sayed et al 1994).

In Egypt, Abd El-Kader and Zaklama (1967) first recorded existence of $P$. citri on lime flowers in Alexandria Governorate. Afterwards, this pest infested many other citrus trees in several Governorates of the Nile Delta (Shehata, 1982; AboSheaesha, 1987; Abd El-Kareim et al 2017). $P$. citri had nine annual generations on lime trees (Abd El-Kader and Zaklama, 1967; AboSheaesha, 1987). However, it had 11 generations a year on lime trees (Shehata, 1982).

$P$. citri larvae feed on flower buds, flowers, newly formed fruits, leaves and shoots of lemon and lime trees (Liotta and Mineo, 1962; Shehata, 1982; Abo-Sheaesha, 1987; Mineo, 1993; Carimi et al 2000; EFSA, 2008). The larvae preferably 
feed on reproductive organs and interior petals of lemon flowers. They also attack mesocarps and seeds of newly formed fruits causing premature fruit dropping (Liotta and Mineo, 1962). P. citri larvae bore beneath rinds of different citrus fruits forming galls, which remain open at tips for destructively invasive fungi (Garcia, 1939). The heavy infestation of $P$. citri caused $30-40 \%$ loss of citron crop (Talhouk, 1969; Perez-lbaniz et al 1973). P. citri infestation was over $50 \%$ on flowers and fruits of lemon, but it reached $100 \%$ on flowers in May and June (Mineo et al 1980).

Seasonal changes of $P$. citri larvae were investigated on lime trees in Egypt (Shehata, 1982; Abo-Sheaesha, 1987). The present work aimed to study population fluctuations of immature stages of this pest on lime trees for better timing of control tactics.

\section{MATERIALS AND METHODS}

Population fluctuations of $P$. citri immature stages on lime flower buds, flowers and newly formed fruits were estimated at ElKanater EIKhairia region, EIQalubia Governorate throughout two successive seasons from 9 April, 2015 to 30 March, 2017.

A lime orchard of half feddan was selected for sampling. Trees were monthly sprayed with different insecticides to control insect pests including $P$.citri for maintaining high production of lime fruits. Weekly samples of 50 flower buds, 50 flowers and 50 newly formed fruits were collected randomly from lime trees. These samples were placed separately in plastic bags and transferred to the laboratory, where they were examined carefully under a stereomicroscope. Numbers of eggs, larvae and pupae of $P$. citri on tree parts were counted and recorded.

The analysis of variance (ANOVA / F test) was used to analyse the variance among insect stages, tree parts and season months. L.S.D. test was applied to compere among means of treatments. The simple correlation was computed to show the relationship between mean numbers of immature stages and daily means of temperatures or relative humidities throughout the two seasons.

\section{RESULTS AND DISCUSSION}

Population fluctuations of $P$. citri immature stages were calculated monthly and expressed as mean numbers of eggs, larvae and pupae. Results obtained are presented in Tables 1, 2 and graphically illustrated in Figs. 1, 2.

\section{1- The first season (2015-2016)}

The seasonal abundance of $P$. citri immature stages on lime flower buds, flowers and newly formed fruits fluctuated throughout successive counts during 2015/2016 season (Table 1 and Fig. 1). Mean numbers of immature stages on flower buds showed six population peaks of 13.3, $1.2,1.8,6.2,2.8$ and 3.4 in mid-May, mid-Oct., mid-Nov., mid-Dec., mid-Feb. and mid-Mar., respectively. On lime flowers, five peaks of 13.5 , $14.5,1.8,5.8$ and 5.0 immature stages were observed in mid-Apr., mid-June, mid-Oct., mid-Dec. and mid-Mar., respectively. Five peaks of 7.3, 0.4, 2.2, 1.8 and 2.4 immature stages were also recorded on newly formed fruits in mid-June, mid-Oct., mid-Dec., mid-Feb. and mid-Mar., respectively. The general mean was the highest (11.3 immature stages) in June, while it was the lowest $(0.0$ immature stage) in Sep. The highest population density of $P$. citri occurred in spring, followed by summer then winter and autumn. The seasonal mean was 4.1 immature stages in the first season.

\section{2- The second season (2016-2017)}

Population fluctuations of $P$. citri immature stages on lime flower buds, flowers and newly formed fruits continued throughout subsequent records during 2016/2017 season (Table 2 and Fig. 2). On flower buds, six peaks of 12.8, 2.5, 4.0, $5.8,3.3$ and 4.6 immature stages were recorded in mid-May, mid-Oct., mid-Nov., mid-Dec., mid-Feb. and mid-Mar., respectively. Mean numbers of immature stages on lime flowers also showed six peaks of $14.5,2.8,5.3,7.2,4.3$ and 5.6 in midApr., mid-Oct., mid-Nov., mid-Dec., mid-Feb. and mid Mar., respectively. Six peaks of 5.8, 1.0, 1.8, 3.0, 1.5 and 2.4 immature stages were also found on newly formed fruits in mid-May, mid-Oct., midNov., mid-Dec., mid-Feb. and mid-Mar., respectively. The highest general mean was 10.8 immature stages in May, while the lowest was 0.0 immature stage in Sep. The highest population density of $P$. citri occurred in spring, followed by summer then winter and autumn. The seasonal mean was 4.6 immature stages in the second season.

$\mathrm{F}$ test showed that there were highly significant differences among insect stages, tree parts and season months of the two years. Moreover, the correlation was insignificantly positive between mean numbers of immature stages and the temperature. However, it was highly significantly negative regarding the relative humidity. 


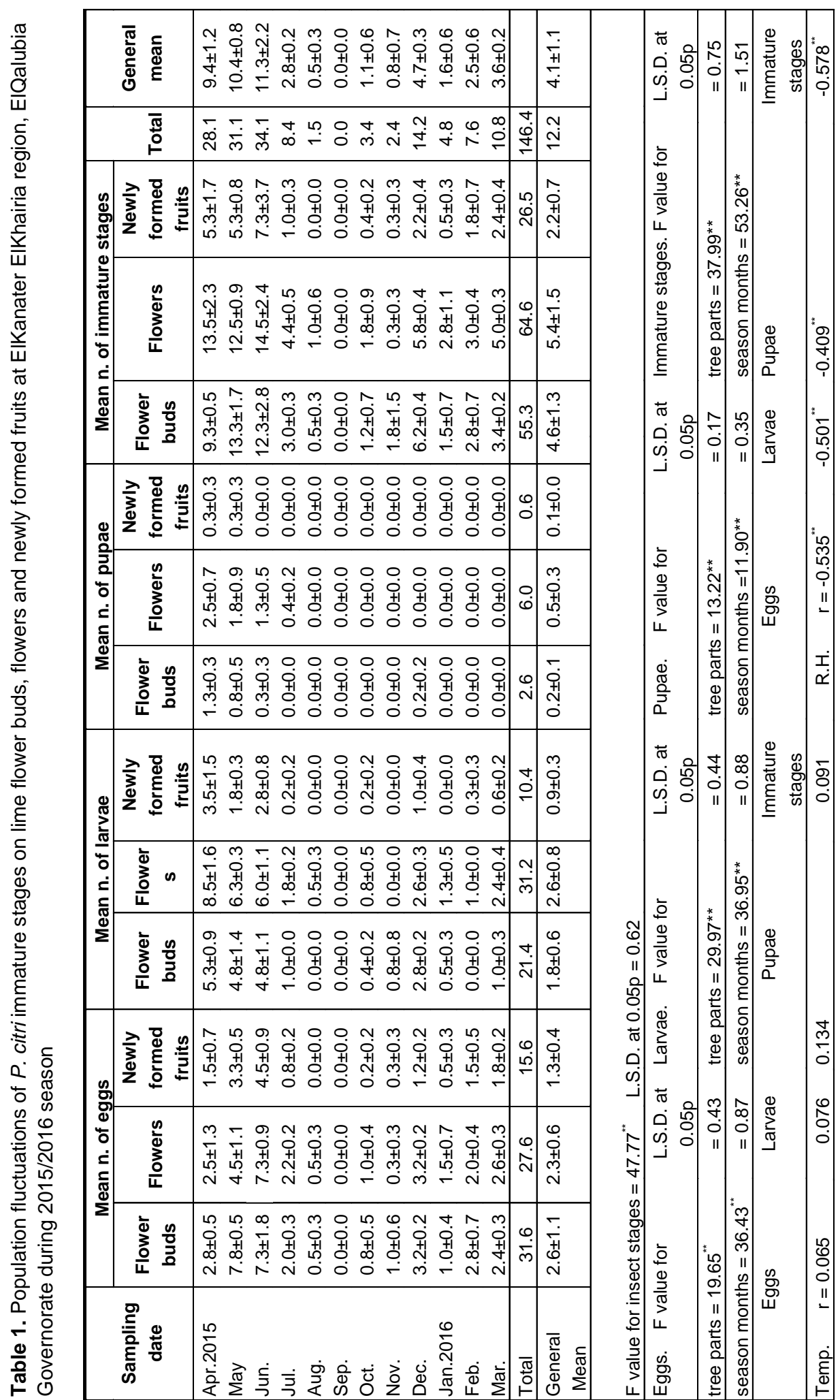




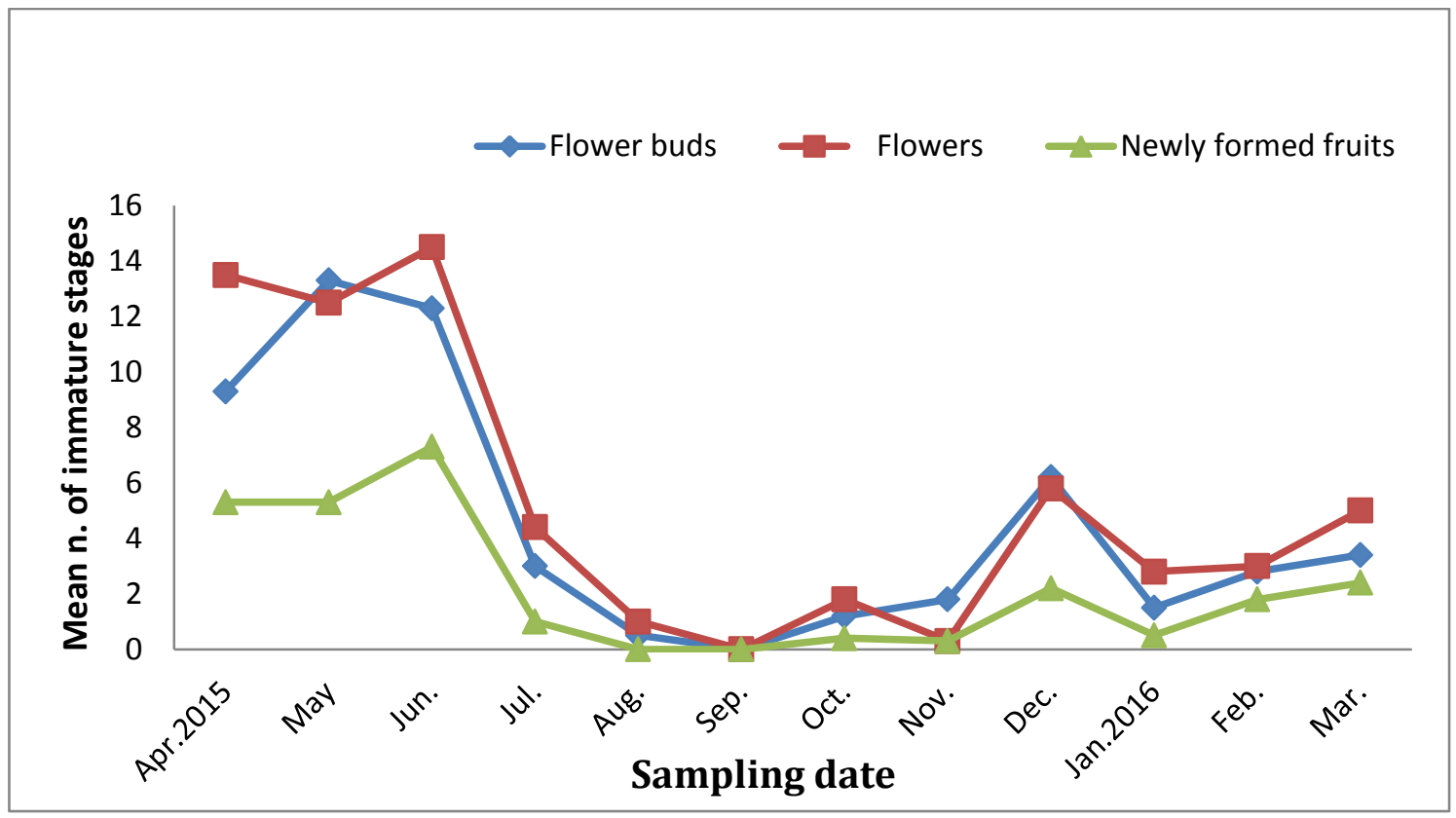

Fig. 1. Population fluctuations of $P$. citri immature stages on lime flower buds, flowers and newly formed fruits at ElKanater EIKhairia region, EIQalubia Governorate during 2015/2016 season

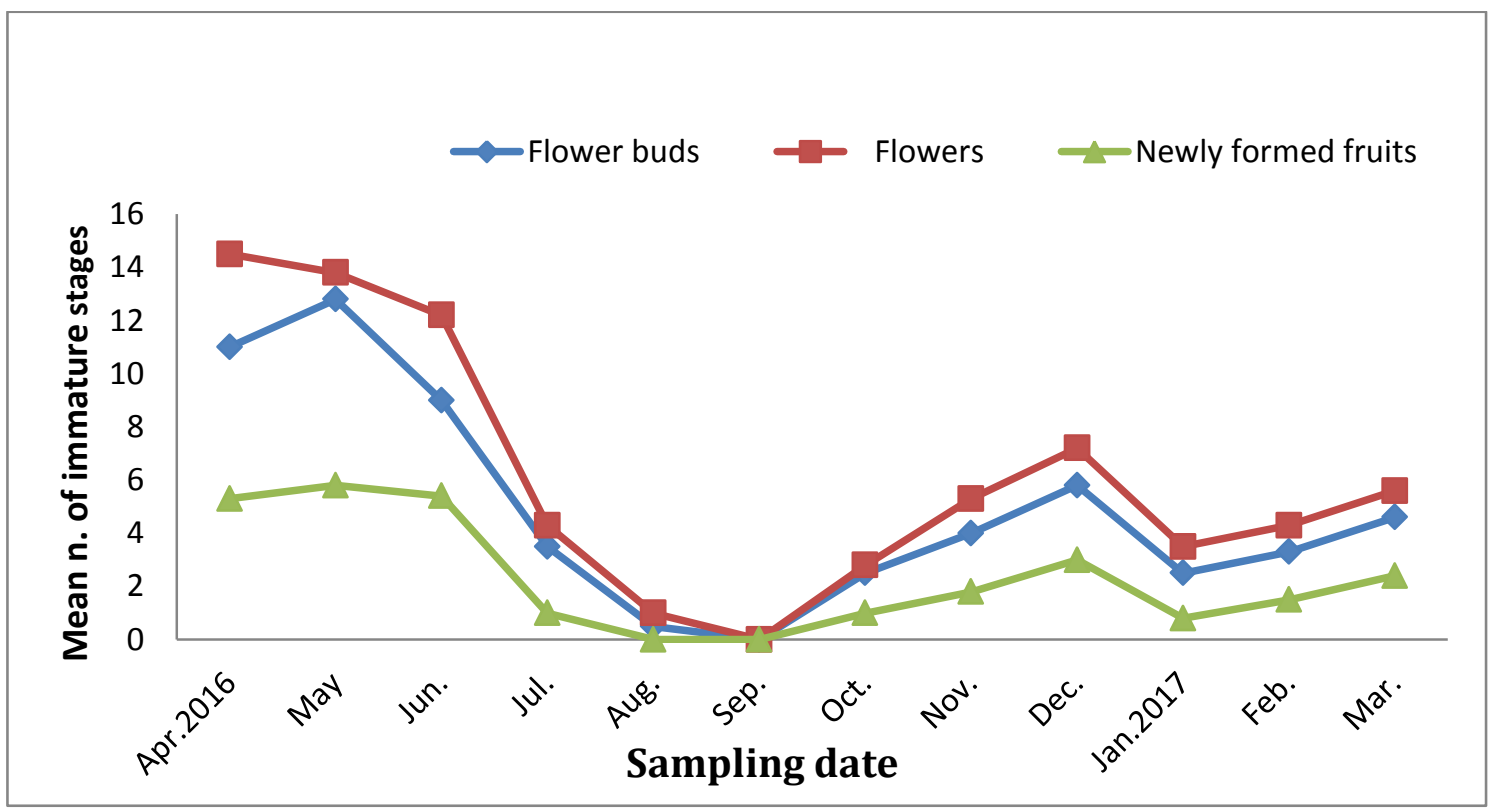

Fig. 2. Population fluctuations of $P$. citri immature stages on lime flower buds, flowers and newly formed fruits at EIKanater EIKhairia region, EIQalubia Governorate during 2016/2017 season. 
Population fluctuations of immature stages of the citrus flower moth, Prays citri Mill. (Lep.: Hyponomeutidae) on lime trees




Similar population trends were reported by Abo-Sheaesha (1987) who found that the population density of $P$. citri larvae was high on lime trees from late April to early July with an outstanding peak in late June and low larval population from January to March. Trends of larval population fluctuations were almost the same in 1983 and 1984. Quayle (1938) stated that $P$. citri larvae prevailed on lemon blossoms from April to November and peaked in mid-summer in Italy. Buchelos et al (1963) recorded a sudden increase in the population density of $P$. citri larvae on lemon flowers in late May. Subsequent generations of this pest continued to attack flowers of lemon and citron until next February. Abd El-Kareim et al (2017) indicated that larval and pupal populations together of $P$. citri on lime flowers exhibited one abundance peak of 2.5 and 2.2 individuals on 10 April, 2015 and 1 April, 2016, respectively. Two seasons of the flower sampling started from 20 February to 24 April. P. citri populations showed a positive response to the mean temperature, while they exhibited a negative correlation with the mean relative humidity.

On the other hand, Shehata (1982) reported that $P$. citri larvae occurred on lime trees all the year round. The larval population on flowers showed 10 peaks between April 1978 and January 1979. Three periods of the maximum larval population on fruits were recorded in mid-June, mid-July and late September of the two years, respectively. Abo-Sheaesha (1987) found that autumn was characterized with the highest abundance for $P$. citri larvae, followed by summer, spring and winter. Bodenheimer (1951) indicated that $P$. citri larvae occurred on flowers of citron and lemon in September and reached their maximum abundance from January to March in Palestine. Mineo et al (1991) showed that eggs and larvae of $P$. citri were found on lemon trees all the year round in Italy. They were more abundant in the $1^{\text {st }}$ three weeks of January, from early May to mid-July and from late August to late December.

Conclusion: Based on the current data, control measures against $P$. citri on lime should be applied from late April to early May to deter adult females from laying eggs resulting in low pest infestation.

\section{REFERENCES}

Abd El-Kader, S. and Zaklama, S. 1967. New records of two insects (citrus flower moth,
Prays citri Mill. and boring orange moth, Cryptoblabes gnidiella Mill.) which attack lime flowers in Egypt and preliminary experiments for their chemical control. The $2^{\text {nd }}$ Arab. Horticul. Conf., 12 p.

Abd El-Kareim, A.I., Moustafa, S.A., Dina M. Fathy and Amara, T.M. 2017. Ecological and biological studies on the citrus flower moth, Prays citri Millière (Lepidoptera: Hyponomeutidae). J. Plant Prot. and Path., Mansoura Univ., Egypt, 8(8), 397-402.

Abo-Sheaesha, M.A. 1987. Ecological studies on Prays citri Mill. (Hyponomeutidae, Lepidoptera) and its control. M.Sc. Thesis, Fac. Agric., AlAzhar Univ., Egypt, 83 p.

Abo-Sheaesha, M.A. 1994. Studies on Prays citri Mill. (Lepidoptera, Hyponomeutidae) and its control. Ph.D. Thesis, Fac. Agric., Al-Azhar Univ., Egypt, 134 p.

Anonymous, 1982. Prays citri Mill. Distribution Maps of Pests, Series A (Agricultural), Map No. 443. London, UK: Commonwealth Agricultural Bureaux.

Bodenheimer, F.S. 1951. Citrus entomology in the Middle East: The citrus flower moth (Prays citri Mill.). Hoitsema Brothers Groningen, Holland, $663 \mathrm{p}$.

Buchelos, T.C., Soweref, S.T. and Tsokas, T.A. 1963. Observations on the biology of Prays citri Mill. in Greece. Rep. Minist. Agric., Phytopath. Sat. 26 p. (c. f. R. A. E. 53: 420).

Carimi, F., Caleca, V., Mineo, G., Pasquale, F. and Crescimanno, F.G. 2000. Rearing of Prays citri on callus derived from lemon stigma and style culture. Entomol. Exper. Appl. 95, 251-257.

Conti, F. and Fisicaro, R. 2015. Integrated strategies to monitor and control citrus flower moth, Prays citri (Lepidoptera: Hyponomeutidae) on nursery trees of the Mediterranean area. Acta Horticul. 1065, 1165-1171.

EFSA (European Food Safety Authority) 2008. Pest risk assessment made by France on Prays citri considered by France as harmful in French overseas departments of French Guiana, Guadeloupe and Martinique1. The EFSA J. 680, 2-22.

El-Sayed, E.M.,Talaat, M.S., El-Desouki, S. and Abo-Sheaesha, M.A. 1994. Bioelectrical activity of citrus flower moth, Prays citri and host plant selection for oviposition. Egypt. J. Biomed. Engin. 10, 31-48. 

Prays citri Mill. (Lep.: Hyponomeutidae) on lime trees

Garcia, C.E. 1939. The citrus rind borer and its control. Philip. J. Agric. 10(1), 89-92. (c. f. R. A. E. 28, 32-33).

Ibrahim, S.S. and Shahateh, W.A. 1984. Biological studies on the citrus flower moth Prays citri Milliere in Egypt. Arab J. Plant Prot. 2(1), 4-9.

Liotta, G. and Mineo, G. 1962. Observations and tests on the control of Prays citri (citrus moth). Note Fitopath. Ist Entomol. Agric., \& Oss. Reg. Mal. Piante (21), 23 p. (c. f. R. A. E. 52: 83).

Mineo, G. 1993. Effects of cultural techniques on the control of citrus flower moth (Prays citri Mill.) infestations (Lep.: Hyponomeutidae). Frust. Entomol.16, 89-95.

Mineo, G., Sciacchitano, M.A. and Sinacori, A. 1991. Observations on the phenology of the preimaginal stages of Prays citri Mill. (Lep.: Hyponomeutidae). Redia 74(1), 225-232.

Mineo, G., Mirabello, E., Busto, T. and Viggiani, G. 1980. Catches of adults of Prays citri Mill. (Lep., Hyponomeutidae) with pheromone traps and progress of infestations in lemon groves in eastern Sicily. Boll. Labora. Entomol. Agrar. 37, 177-197.
Perez-lbanez, T., Alberti-Maurico, J., MartinezCanales, G. and Vinaches Gomis, P. 1973. Development of larvae of Prays citri Mill. in the months of April, May, June and July. Bol. Inform. Plag., 108, 17-27.

Quayle, H.J. 1938. Insects of citrus and other subtopical fruits. Comstock Publishing Company, Inc. Ithaca, New York, USA, 212 p.

Shehata, W.A. 1982. Biological, ecological and control studies on the citrus flower moth, Prays citri Miller (Lepidoptera: Hyponomeutidae). M.Sc. Thesis, Fac. Agric., Cairo Univ., Egypt, 111 p.

Silva, E.B., Gaspar, R., Dias, L., Antunes, R., Lourenco, I., Clemente, J. and Franco, J.C. 2006. Developing a mating disruption tactic for pest management of citrus flower moth. Bull. OILB/SROP 29(3), 127-137.

Talhouk, A.M. 1969. Insects and mites injurious to crops in Middle Eastern Countries. Text Book, Verlag Paul Parey, Hamburg and Berlin, pp. 21-24.

Toth, M., Tabilio, R. and Franco, F. 2009. Developing semiochemical tools for monitoring, mass trapping and integrated control of potential pests of citrus and Mediterranean fruit crops. Protez. Colt. 3, 34-39. 


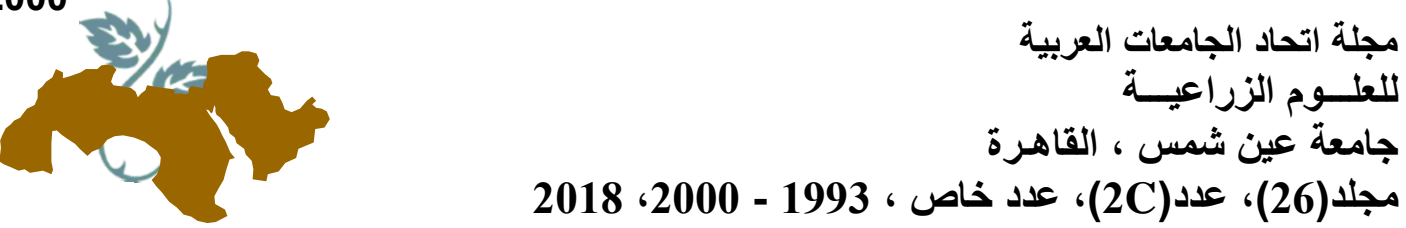

تقلبات تعداد الأطوار غير البالغة لفراثة أزهار الحمضيات (الموالح)، بريز سيترى ميلل (رتبة

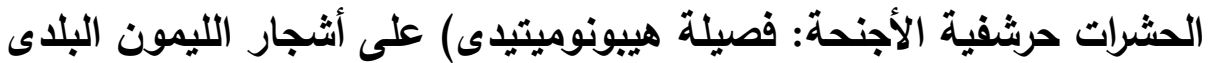

[147]

\author{
أحمد فرج بلر - عبدالمحسن محمد هيكل - لطقى عبدالحميد يوسف \\ قسم وقاية النبات - كلية الزراعة - جامعة عين شمس - ص.ب. 68 حدائق شبرا 11241 - القاهرة - مصر
}

المتوسط الموسمى 4.1 أطوار غير بالغة خلال الموسم

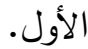

أمكن تطبيق نفس الإتجاة خلا موسم

2017/2016. أظهرت النتائج ستة ذانجاء ذروات هـى

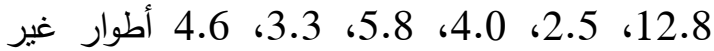

بالغة على البراعم الزهرية فى منتصف شهور مائونايو وأكتوبر ونوفمبر وديسمبر وفبراير ومارس على فلى التوالى الثي.

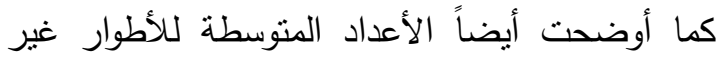
البالغة على الأزهار ستة ذروات منوالية هى 14.3 14.3،

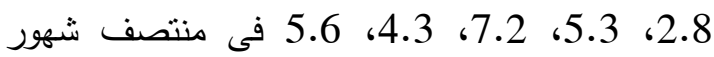

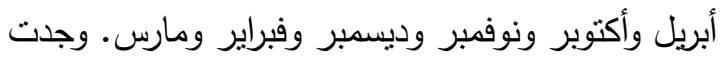

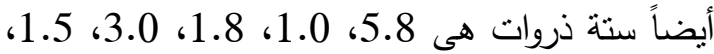

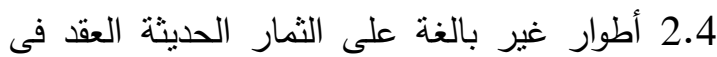
منتصف شهور مايو وأكتوبر ونوفمبر وديسمبر وفبراير

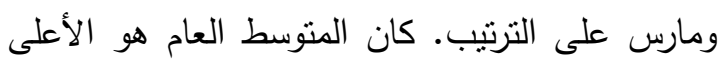
(10.8 أطوار غير بالغة) فى مايو والأدنى (صفر الغرن

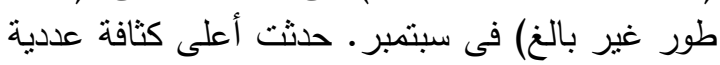
للحشرة فى فصل الربيع يليه الصيف ثم الثنتاء والخريف. كان المتوسط الموسمى 4.6 أطوار غير لفئ

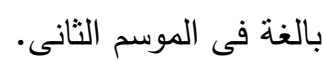

الكلمات الادالة: فراشة أزهار الموالح، تقلبات التعداد،

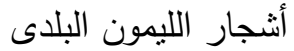

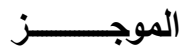

تم تسجيل ستة ذروات عددية لمتوسط أعداد الأطوارغيرالبالغة لفراشة أزهار الحمضيات (الموالح)



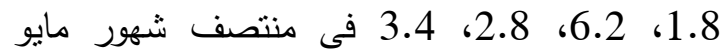
وأكتوبر ونوفمبر وديسمبر وفبراير ومارس على النوالى فئى خلال موسم 2016/2015. لوحظت خمسة ونسير ذروات عددية هى 13.5، 14.5، 1.8، كوديم 20.8 5.8،

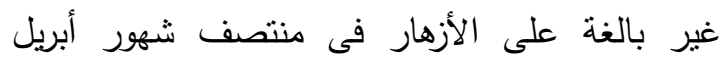

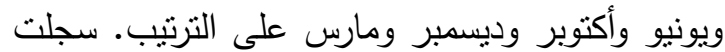

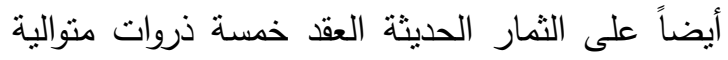
هى 7.3، 0.4، 2.2، 1.8، 2.4 أطوار غير بالغة دئة فى منتصف شهور يونيو وأكتوبر وديسمبر وفبراير ومارس. كان المتوسط العام هو الأعلى (11.3 أطوار غير بالغة) فى يونيو والأدنى (صفر طور غير العير بالغ)


فصل الربيع يليه الصيف ثم الثتاء والخريف. كان 


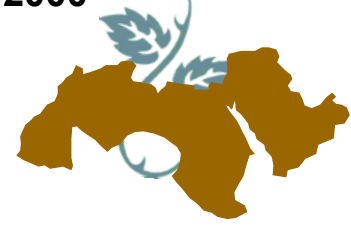

$$
\begin{aligned}
& \text { مجلة اتحاد الجامعات العربية }
\end{aligned}
$$

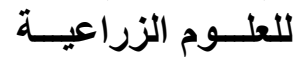

جامعة عين شمس ، القاهرة

مجلا(26)، عدد (2C)، عدد خاص ، 1993 - 2000، 2018 